\title{
Individual Education Planning (IEP): Equipping Teachers in Addressing Learners' Diversity
}

\author{
Elymar A. Pascual \\ elymarpascual@rocketmail.com \\ Department of Education, Nagcarlan District, Nagcarlan, Laguna, Philippines, 4002
}

\begin{abstract}
This study aimed at exploring the formal and non-formal ways of producing learner's profile that would aid in developing Individual Education Planning which would best suit learners' needs, interest, strengths and weaknesses, thereby leading them in having holistic development. This research employed a qualitative technique in doing research, which according to Creswell (2003) delves mainly on inquiry to produce responses and themes. Forty-one grade 11 learners in Accountancy, Business and Management (ABM) and General Academic Strand (GAS) of Talangan Integrated National High Schoool, Nagcarlan, Laguna became the respondents for this study. Three methods of acquiring profile that was introduced in this study are home visitation, use of learners' cardex, and homeroom guidance program. After one semester of conducting the aforementioned activities, written interview to the learners were done. The themes that were generated for home visitation are as follows: (1) Home visitation is a channel of ac acquiring basic knowledge for the learners' situation at home, (2) way of uplifting learners' by showing concern to his life outside school, (3) teacher's basis for management of lesson and learners in classroom setting, (4) important for learners acquisition of confidence in being his real self at home and inside the classroom, (5) assessment of background of learners so teachers can institute appropriate discipline inside the classroom, (6) collaboration with learners' family in ensuring utmost performance of learners, and (7) school's duty to relate to community as part of learners' environment. The use of learners' cardex was seen as (1) source of basic knowledge of learners' strength and weaknesses, (2) a monitoring agent that guides learners' progress on a task or challenges he is encountering, (3) an assessment of learners' needs and how teachers and parents can help, (4) a reminder to learners that everyone is unique and they need not to compare themselves to others, (5) a reward in itself when learners realize their achievements, (6) a mirror of learners life path which aids them in inner introspection, and (7) an important mechanism that aids learners in regular assessment of their development. Homeroom guidance program was deemed as (1) a way of nurturing themselves in other aspect of human development like spirituality, (2) a venue for learning and relearning lessons taught in schools, (3) a beneficial intervention when planned with specific activity, (4) a time set for learners and teachers to know and be acquainted with each other, (5) a special way to take away barrier between teacher and learner or between learners themselves, (6) an avenue that will aid teachers in developing lessons suited for the learners needs, and (7) a way to provide guidance for learners and motivate them to schooling. Lastly, better academic performance was observed when these three activities were done. Recommendation to teachers, parents, school heads, curriculum developers and future researchers were given at the end of the study.
\end{abstract}

Keywords: individual education planning; home visitation; learner's need; progress; achievement; homeroom guidance program

\section{Introduction}

Individual Education Plan (IEP) has been in the educational setting since 2001 and was popularized by United Kingdom and Canada. It began with the concept of bringing education to special children who have specific needs, and later was adopted by institutions as strategy of meeting different needs of learners. It's a strategy of bringing individual education to each learner through compilation of information and records of dealings between teacher, parents and learner. With the onset of the new Philippine Professional Standards for 
Teachers last 2018, the challenge of addressing learners' diversity and collaborating with parents to attain utmost learning experience from the students was laid down. This paper intended to explore the benefit of using individual education planning to the performance of learners in school. Particularly, the researcher wanted to build on home visitation, learner's cardex of needs-progress-achievement, and homeroom guidance program as three ensuring ways to possibly address learners' diversity. These strategies were used and explored during the first semester of the school year 2019-2020 for the grade 11 GAS and ABM learners that the researcher was handling as advisory sections in Talangan Integrated National High School, Nagcarlan, Laguna. Responses of learners were recorded as part of the study.

\subsection{Background of the Study}

Since the onset of the K to 12 Basic Education Curriculum, otherwise known as the Enhanced Basic Education Act of 2013, Talangan Integrated National High School has accepted the challenge of accepting Senior High School Students, offering both academic and technological-vocational courses. From school years 2016-2017 and 2017-2018, it has offered General Academic Strand (GAS), Automotive and Caregiving strands, while from school year 2018-2019 until this present school year, it has added Accountancy, Business and Management (ABM) and Information, Communication and Technology (ICT). The combined enrolment of grade 11 and 12 is 374 , and its present head is the hardworking Mrs. Josefa U. Orijola, Principal II.

The grade 11 GAS and ABM are fused into one section as the 11 Vibrant and its adviser is the researcher. The section consists of 9 male and 32 female, with a total of 41 learners. The school is strictly following the mandate of RA 10533, or the Enhanced Basic Education Curriculum, in delivering the needed competency for the SHS students. Nevertheless, it is an understatement that all learners have different learning styles, multiple intelligences, emotional quotient, and even spiritual intelligences. Therefore, the challenge of bringing a touch of individual education program is being considered in this study.

\subsection{Theoretical Framework}

The Individualized Educational Planning (2005) of Prince Edward Island, Canada looks at the routine or cycle of having an individualized education program like the two legs of a triangle or pyramid where the left part relies solely on existing provisional mandate on education in their country, and the other side shows the process being undergone in having an individual education program.

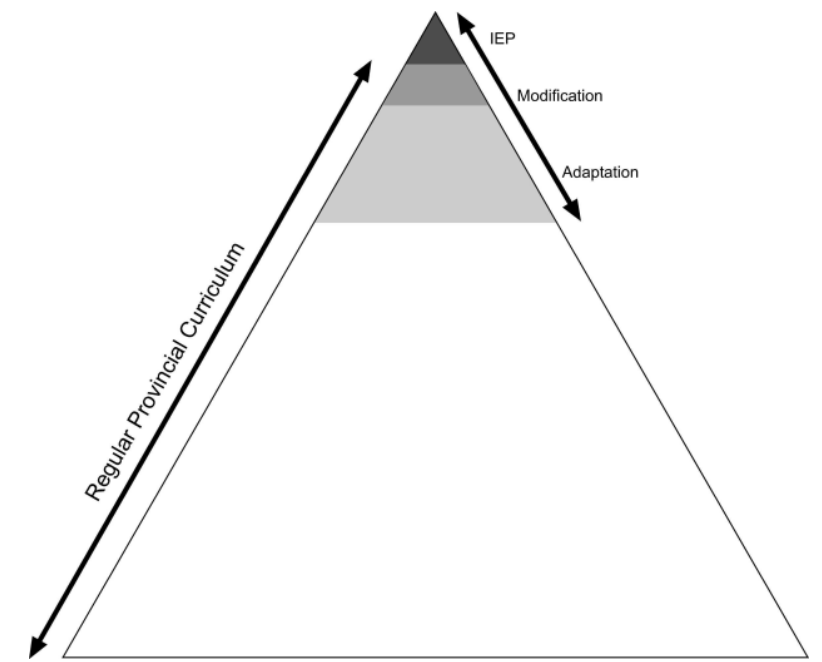

Fig. 1. Process of developing an IEP 
After that the regular provisional curriculum was considered, looking into the profile of the learners will lead an educational institutional to develop an IEP. The IEP team will review the developed IEP, making some edition, addition or changes based on the capability of the school and the support given by parents and other stakeholders. Lastly, the adaptation to classroom setting will determine if the IEP produced will suit the needs, interest, orientation and individual differences of the learners.

Also, from Individualized Educational Planning (2005), the first seven definitions and description of IEP were highlighted:

- Individualized educational planning is a process by which educators, support personnel and parents collaborate to ensure that students' needs are addressed in a systematic manner.

- The individualized educational planning process provides a mechanism to ensure that an IEP is developed and implemented through a structured format that clearly outlines the steps to be followed.

- The individualized educational planning process provides a framework for decision-making that is informed by a clear understanding of the student's present level of performance.

- Individualized educational planning is initiated for students whose programs vary significantly from the prescribed curriculum and/or who have special educational, medical, behavioral, and/or physical needs.

- The individualized educational planning process relies on information collected from a range of informal and formal assessments.

- The individualized educational planning process is strengthened by the authentic and continued involvement of parents at all stages of planning, development and implementation.

- The individualized planning process mandates the formation of a collaborative individual education planning team when the result of the formal referral process indicates the need for individualized programming.

Out of this seven definition and description, the fifth item is the one that encapsulates this present study in such a way that this paper will not go as far as developing an IEP team, but just looking into possible sources for having learners' profile, and thus, leading teachers to battle against learners' diversity. Those sources of learners' profile present in this study are home visitation, use of learners' cardex, and homeroom guidance program.

\subsection{Conceptual Framework}

Fig. 2. The paradigm

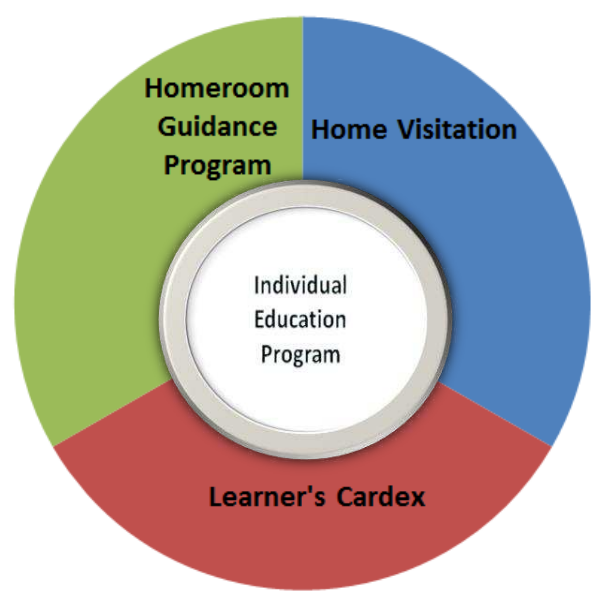


This study evolved in the notion that important in conceptualizing an individual education program is having learners' profile that can be extracted from formal and informal activity and assessment. Those three sources that this study explored are home visitation, use of learners' cardex, and homeroom guidance program.

\subsection{Statement of the Problem}

This research intends to record and analyse the view of learners, teachers and parents with Individual Education Planning (IEP) in terms of its role in equipping teachers in addressing learners' diversity.

Specifically, it seeks to answer the following questions:

- What is the learners' view to the following components of Individual Education Planning (IEP):

* home visitation?,

* use of learners' cardex containing needs, progress and achievement?,

* homeroom guidance program?;

- What was the learners' general average during the first and second quarter of the school year 20192020 ?

- Did the conduct of home visitation, utilization of learners' cardex and implementation of homeroom guidance program helped in improving learners' academic performance?

\subsection{Significance of the Study}

This study would benefit the following group of people - learners, teachers, parents and community. Through this research, learners would see education as not just schooling but a second home where they meet their second parents. Teachers would be filled with information about their learners that would aid in preparing lessons adjusted to learners' need. Parents would see homes as extension of learning. Communities would be indirectly benefitted in having the youth nurtured and trained with values of caring.

\subsection{Scope and Limitation}

Individual Education Plan can be considered the sister of curriculum planning because through IEP, the best fit education is brought to the classroom setting without having the minimum competency required by the curriculum being put in jeopardy. Therefore, IEP is a broad process of looking into the learners' profile, convening an IEP team, localizing the materials and concept found in the curriculum, reviewing the initial IEP, and adapting the program. This entire process of having an IEP, specifically for Talangan Integrated National High School where this study is conducted, was not covered, but just the primary part of knowing where the profile of the learners can be obtained in such a way that it will cater and vastly benefit in the entire process of having an IEP for different schools. The components that became part of the study were home visitations, learners' cardex, and homeroom guidance program.

\section{Related Literature}

This part of the paper highlights the studies and writings published that has direct or indirect connection to the topic discussed in this research.

\subsection{Individual Education Planning and Learners' Diversity}

UNESCO (2004) in its introduction to "Changing Teaching Practices - Using Curriculum 
Differentiation to Respond to Students' Diversity" states that "flexibility in attitudes and practice can help teachers in addressing the changing needs of children, their families and society as a whole. ... Teaching and learning are effectively about collaboration, working together. ... Schools that create an environment where experimentation and sharing is encouraged can begin to change." This emphasizes that flexibility of teachers is a key attitude in dealing with learners' diversity which individual education planning revolves around. Furthermore, when a school or teacher makes use of differentiated instruction, it does not necessarily mean that it is already having individual education program, rather, it is just having balanced teaching strategy. "Differentiated curriculum is a way of thinking ....about...students...how we teach and how they learn .... what they really need to learn in school ...providing instruction that meets the needs, abilities and interests of our students....how...students...successfully learn the skills and concepts we want them to learn." (UNESCO, 2004) Having differentiated instruction doesn't already mean that IEP is being implemented, but a school operating on IEP system cannot go away with having differentiated instructions on every classroom setting.

A concept connected to differentiated instruction which characterizes an IEP setting is the multi-level instruction which is developed and popularized by Gordon Porter, Julie Stone and Jean Collicut. This strategy focuses on one main lesson but has variety of presentation, practice, and evaluation techniques, thus inviting learners to perform and participate though they may have level of ability and interests. "The key is in determining the underlying concepts and learning outcomes of the lesson, considering them in the light of the students with special educational needs, and making adaptations as needed for those who require them." (Porter, 1994) Multi-level instruction as part of IEP, thus, needs the profile of learners to determine the special educational needs and have the strategy and lesson delivery fit learners' diversity.

Bennett, Barrie \& Rolheiser, and Carol (2001) in their "Artful Science of Instructional Integration" offers a perspective in IEP in which both teachers should be encouraged in growth and development in management of lesson so they can provide powerful environment for learning not only for the learners but for the teachers as well. Barrie Bennett's work as a teacher and a researcher focuses on instructional intelligence. He believes that the teaching profession is fulfilling but at the same time complex, that is why he worked collaboratively with teachers so as to explore meaningful strategies that would make a difference for present and in the future.

\subsection{Homeroom Guidance Program}

In order to battle against learners' diversity, homeroom guidance program can provide information to teachers with regards to learners' strengths and weaknesses. The writings of Bennett shows how he wanted to have a change in public education system, starting from few teachers who would embrace challenges, and then affecting the school and the whole education itself. He wants teachers to "experience, understand and apply how to integrate a variety of instructional concepts, skills, tactics, and strategies in the design of more powerful learning environments...with a focus on literacy." (Bennett 1991). His concept does not only imbibe vibrancy on the academic side, but on the heart of the teachers and learners as well. On this note, the role of teachers and advisers on handling homeroom guidance program is vital.

It is a usual notion that teaching has two facets - the art and the science. Bennett popularize what he calls the "the science within the art of teaching." Teachers' task is not just to apply the best way of teaching because there is no concept like that when learners do not work on putting together their collective intelligence and apply what they have learned. This is where homeroom guidance program plays a vital role in leading learners towards thinking of the society and not just themselves as they learn concepts to be used in practical life.

\subsection{Learners' Cardex}

Aside from homeroom guidance program, another way to assess learners and keep a record of their 
profile is through learners' cardex. Te Puri Kokiri (2007) describes the basic nature of a cardex which can be used in communicating to stakeholder the needs, achievement and progress of a child. He also proposed communication through various means of media technology.

Through the use of the information found in cardex, teachers can make tailor-made instructions in order to meet individual needs. A teacher can initiate differentiated instruction in four aspects - content, process, product, and learning environment. There might be the target competency but the content can be adjusted based on the learners' needs and interest. The process of delivering knowledge is different with the academic group than those in technological-vocational strand. The output or outcome of a teaching session can deeper based on the track a student chose in SHS. And lastly, the learning environment should suit the learners experience and preferred future career. Doing adjustments on content, process, product and learning environment without sacrificing the needed competency would put the learners in performing to their utmost. And this differentiation in instruction can be based on the learners' cardex where the needs, progress and achievement are recorded.

\subsection{Home Visitation}

Epstein (1995) developed a model with four established pattern with regards to the partnership of school and community.

- Partnerships between home and schools tend to decrease across grades unless schools develop and implement appropriate partnership practices at each grade level.

- Affluent communities have more family involvement on average, unless schools in distressed communities work to build positive relationships with students' families.

- Schools in distressed communities tend to make more contact with families about problematic behavior, unless a balanced partnership program that includes contacts about the positive accomplishments of students is established.

- Fathers, parents who are single, who are employed outside the home, or who live far from the school tend to be less involved at the schools, unless the school organizes opportunities for families to volunteer at various times and places to support the school and children.

Pascual (2019) in his book entitled 'Essentials of Home Visitation: Teachers', Learners' and Stakeholders' View" enumerated five benefits of home visitation:

- Establishing contract between teacher, learner and parents. - This aspect of partnership is important for school and community can go hand-in-hand in nurturing the youth of today. If the guiding principle in school is the same as at home, there will be no lapse of discipline and the learners would not be confused to what is right and wrong, thereby producing a well-rounded person to an individual.

- $\quad$ Precautionary measure, and not remedy to learner problems - Most of home visits are for followups of learners who are committing absenteeism and are about to drop out from school. But looking into this aspect would cause teachers and educators re-evaluate the effectiveness of home visitation.

- $\quad$ Aid in maintaining good academic performance - The responses in the survey questions supports the result t-test that home visitation has a significant effect to academic performance. Nothing more can be added because it is a clear-cut benefit of home visitation, that increased academic performance follows when there is a healthy home visitation.

- Creating a home extension of learning and evaluation - Home becomes a place for nurturing child, and not just the school, when the teacher gives effort in communicating to parents about the behavior and performance of the learner in school.

- Inculcating responsible citizenship for future leaders in community - Learners see an example of servant-leadership from the teachers, that is why, when these youth become leaders someday, they will also reach out to their constituents and ask them help in bringing the best to their community. 
Home visitation is not just an issue in education, but has been trend in health and nutrition to many countries. Research of Schmit et al (2015) "supports the notion that home visiting programs can enhance parenting and support young children's early development with long-term outcomes for children, parents, and public cost savings." But Byrd (2012) admitted that "Home visits are not a magical solution for every problem. There are many challenges surrounding home visits. On the side of the schools, they take time, which is at a premium for educators. On the side of the families, home visits can be challenging for various reasons."

If the academic performance is the issue, Gorter-Reu \& Anderson (1998) found out that "teachers who make regular home visits feel that it is well worth the time and emotional effort due to the significant payoffs in the classroom." Directly and indirectly, academic performance is positively affected because of the confidence gained by the learner when he is visited and encouraged by the teacher. Even the Tasmanian Department of Education has this guiding principle home visitation, "In order to achieve change and improved learning outcomes for students, it is often necessary to work with or meet family members outside the school environment."

In the article written by Borba (2009) about caring for English learners (Els), he said, "eestablishing firm school-home relations is vital to working with all students and their families, but presents some challenges for ELs." Though these challenges may be present, the reward is indeed outstanding. In the study made by Gichohi (2015), using 52 schools as samples, he found out that result in academic performance is related to the participation of stakeholders in creating school policy. This also has something to do with home visitation because through this teacher activity, the updates in school is being brought to their knowledge, and thus, their response will also be brought to school. The result of this is parallel with the result of the study made by Adjei and others (2008) of South Africa. In their study, they made use of 45 selected private and public schools. They found out that those schools which have a community involvement in school governance has highly effective teachers, thereby greatly contributing to learners' academic performance.

Tondi (2014) of Tanzania made an analysis of the stakeholders' view of the quality of education in their country. Stakeholders lined up many problems and shortcomings in the education system. At the end of his dissertation, Tondi recommended the encouragement stakeholders' participation in the governance of the school. One of the ways this encouragement can be done is through home visitation. NEA President Dennis Van Roekel (2008) of Washington D.C. made a declaration, "Parents, families, educators and communitiesthere's no better partnership to assure that all students pre-K- to high school-have the support and resources they need to succeed in school and in life."

Wang and Haertel (nd) made a comparison between schools with low teacher-parent relationship and those with high level of it. They observed that the impact can be seen in students' learning. Where there is high level of parent involvement, the educational system is seen effective because of good students' learning and well-being. NEA Education Policy and Practice Department of Washington D.C. (2013) encouraged and said, "Parents and community members must have a strong vested interest in the success of the schools and must co-own the outcomes produced."

The above-mentioned readings on home visitation, learners' cardex, homeroom guidance program, individual education planning and learners' diversity help in the establishment of concrete support to the present study.

\section{Research Design and Methodology}

This part of the study discusses the research design, respondents, data gathering procedure, data gathering instrument, ethical consideration, and data analysis for this study. 


\subsection{Research Design}

Qualitative method of doing a research would be the process to be employed to answer the questions posted at the beginning of the study. Creswell (2003) describes qualitative research in three ways which makes this design different from quantitative research: (a) makes knowledge claims based on constructivist perspectives, (b) uses strategies of inquiry, and (c) collects open-ended emerging data with the primary aim of developing themes from the data.

\section{Respondents}

The respondents for this qualitative study were the advisory class of the research which was consisted of Grade 11 Accountancy, Business and Management (ABM) and Grade 11 General Academic Strand (GAS) learners. They have a total of 41 students.

Table 1. Respondents for this study, s.y. 2019-2020

\begin{tabular}{|c|c|c|c|}
\hline Strand & Male & Female & Total \\
\hline ABM & 2 & 17 & 19 \\
\hline GAS & 7 & 15 & 22 \\
\hline Total & 9 & 32 & $\mathbf{4 1}$ \\
\hline
\end{tabular}

3.2. Data Gathering Procedure

In order to answer the questions posted at the beginning of the study, the following processes were done:

- Submission of Action Research Proposal to school head for approval

- Oral and written consent from the advisory class that a study is to be underwent

- Conduct of Home Visitation to 41 learners on first semester of s.y. 2019-2020

- Writing and Assessment on Individual Learners' Cardex containing needs, achievement and progress

- Implementation of homeroom guidance program through weekly breakfast symposium

- Communication to parents of learners needs, progress and achievement

- Written interview with learners regarding the conduct of home visitation, use of learners' cardex, and implementation of homeroom guidance program

- Encoding of answers in written interview

- Analysis of responses through the Word Cloud generator

- Development of themes and conclusion

\subsection{Data Gathering Instrument}

A one-sheet written interview was given to each of the 41 respondents as the researcher gathers their idea about the conduct of home visitation, use of cardex, and institution of homeroom guidance program. The survey question sheet has the following basic content:

As a student, what is your view about the following:

- Home visitation (for every learner even without school offense)

- Learners' Cardex (containing needs, progress and achievement)

- Homeroom guidance program (through breakfast symposium)

\subsection{Data Analysis}

Collected responses were analyzed using software that generates word statistics and world cloud, thus having a way to analyze answers and generate conclusion. 


\section{Presentation, Interpretation and Analysis of Data}

4.1. Home Visitation

Table 2. Word count of home visitation qualitative response

\begin{tabular}{|c|c|c|}
\hline Index & Word & Occurrences \\
\hline 1 & Home & 30 \\
\hline 2 & know & 29 \\
\hline 3 & visitation & 23 \\
\hline 4 & student & 21 \\
\hline 5 & teacher & 19 \\
\hline 6 & important & 13 \\
\hline 7 & background & 9 \\
\hline 8 & family & 8 \\
\hline 9 & good & 7 \\
\hline 10 & school & 6 \\
\hline 11 & adviser & 6 \\
\hline 12 & problem & 5 \\
\hline 13 & house & 5 \\
\hline 14 & life & 4 \\
\hline 15 & situation & 4 \\
\hline 16 & problems & 3 \\
\hline 17 & lot & 3 \\
\hline 18 & make & 3 \\
\hline 19 & things & 3 \\
\hline 20 & attitude & 3 \\
\hline 21 & each & 3 \\
\hline 22 & great & 3 \\
\hline 23 & importance & 2 \\
\hline 24 & learner & 2 \\
\hline 25 & happy & 2 \\
\hline
\end{tabular}

Hupv PROBLEMS ADVISER

\section{Aarearaum STUDENT \\ SCHOOL HOUSE SITUATION}

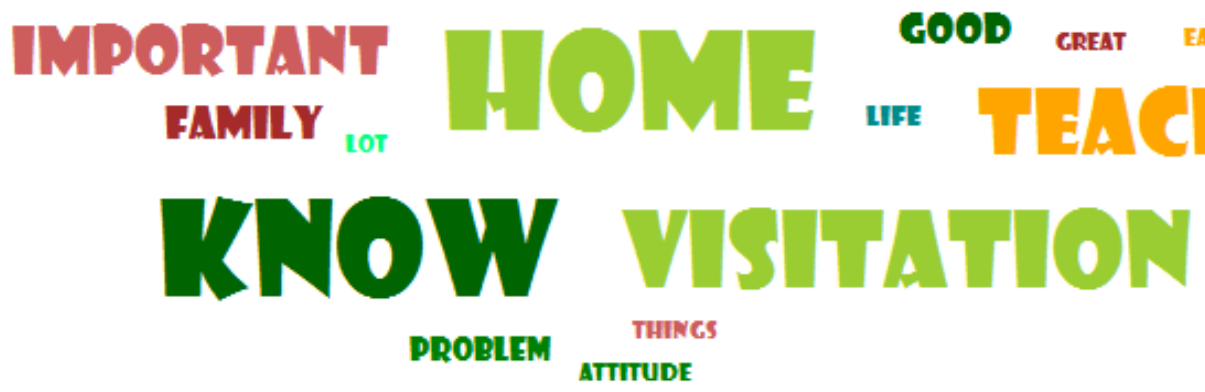

Fig. 3. Word cloud of home visitation qualitative response

The seven words that appear to be significant for learners when home visitation is the issue are the following: know, student, teacher, important, background, family and school. The word "good" which is seen in the $10^{\text {th }}$ spot in the frequency table for home visitation can be combined with the word "important" for they 
bear the same connotation. An analysis of Home Visitation as one aspect of Individual Education Program is thus lined up below.

- Know - Home visitation gives basic knowledge to the teacher/adviser regarding the behavior of learners at home. This can be learned by the teacher visiting through conversation with parents and siblings of the learner, or by observation during the home visit.

- Student - During home visitation, learners see themselves as the focus of the act, thereby creating in their senses their importance to the teacher and to his parent as well. Their value as an individual is being appreciated as the teacher takes time to do extra mile of help.

- Teacher - As the teacher takes time to know the family of the learner, the teacher becomes aware of what classroom strategy can best suit the learners' needs, interest and experience. Flexibility and resourcefulness are thus required when the teacher becomes acquainted with the learners' background.

- Important - Learners look at home visitation as important, though there might be negative connotations with the act because of own experience or as observed in school setting. Visitation is seen as a way of expressing themselves and opening up their life to the teacher, instead of a traumatic experience of being reprimanded by the teacher at home in front of the family members.

- Background - Learner's family, personal, social and cultural background are seen to be the issue of home visitation, and not the discussion of misbehavior done in school. Thus, teachers should really need to develop the system of religiously visiting learners' at home because background information of learners play a big part in management of learning.

- Family - Collaboration with parents or family of the learners is a direct result of home visitation. This opens the communication so that progress, needs and achievement can be easily relayed from school to family or community.

- School - School is seen to be an agent of change when home visitation is done by the teachers. Getting away with the issue of salary or just a day's work, home visitation is a call for diligent educators because it is the life of learners which is at stake. Touching lives is of broader concern, not just touching mind.

This analysis is in consonance with another study conducted by the same researcher. In his study entitled 'Essentials of Home Visitation: Teachers', Learners' and Stakeholders' View (Pascual, 2019), five benefits of home visitation were mentioned: (a) establishing contract between teacher, learner and parents, (b) precautionary measure, and not remedy to learner problems, (c) aid in maintaining good academic performance, (d) creating a home extension of learning and evaluation, and (e) Inculcating responsible citizenship for future leaders in community.

\subsection{Cardex}

Table 3. Word count of cardex qualitative response

\begin{tabular}{|c|c|c|}
\hline Index & Word & Occurrences \\
\hline 1 & know & 17 \\
\hline 2 & cardex & 14 \\
\hline 3 & progress & 13 \\
\hline 4 & needs & 11 \\
\hline 5 & student & 11 \\
\hline 6 & learner & 10 \\
\hline 7 & achievements & 9 \\
\hline 8 & achievement & 8 \\
\hline 9 & life & 6 \\
\hline 10 & students & 6 \\
\hline 11 & important & 6 \\
\hline
\end{tabular}




\begin{tabular}{|l|c|l|}
\hline 12 & because & 6 \\
\hline 13 & you & 6 \\
\hline 14 & need & 6 \\
\hline 15 & help & 5 \\
\hline 16 & or & 5 \\
\hline 17 & they & 5 \\
\hline 18 & as & 5 \\
\hline 19 & achieve & 4 \\
\hline 20 & teacher & 4 \\
\hline 21 & helps & 4 \\
\hline 22 & problem & 4 \\
\hline 23 & Learners & 4 \\
\hline 24 & are & 4 \\
\hline 25 & be & 4 \\
\hline
\end{tabular}

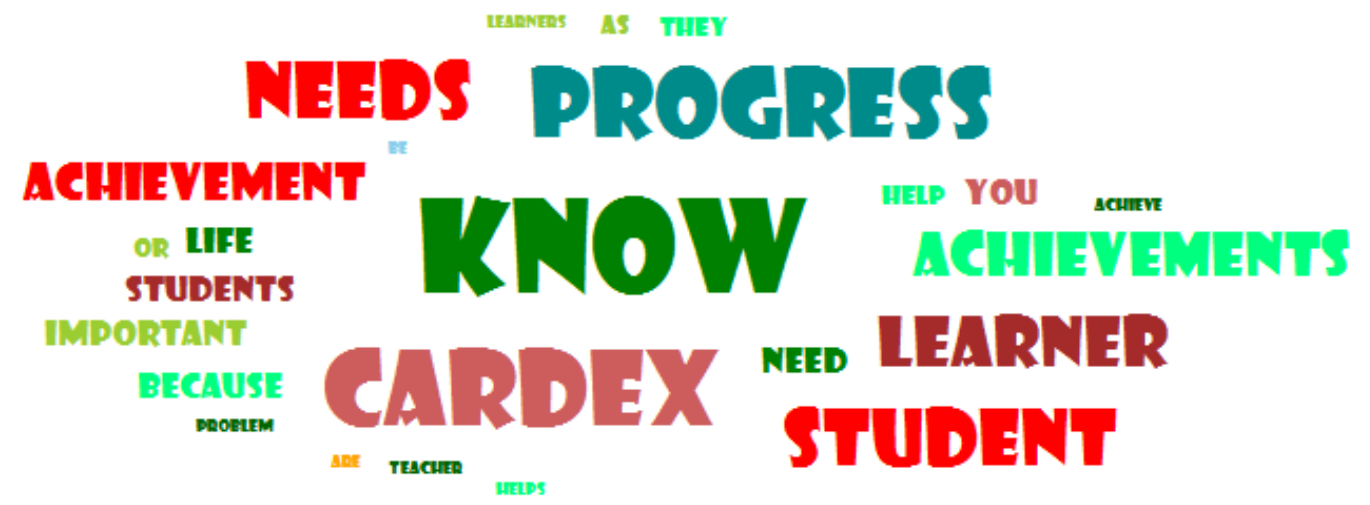

Fig.4. Word cloud of cardex qualitative response

The use of Cardex to record leaners' progress, needs and achievement, and having it communicated to parents to have collaboration in leading learners towards holistic development was also evaluated by learners through a survey with an open ended question. The seven prevailing words in their responses are the following: know, progress, needs, student, achievement, life and important. The themes developed from their responses are as follows:

- Know - Through reflection, learners' are able to distinguish their strengths and weaknesses that will aid teacher in strategizing on lesson planning makes the activities fitted to their ability. Teacher can put together learners in groups so they can collaborate and complement with each other.

- Progress - Being able to recognize one's progress can boost learners' confidence and trust in themselves, thereby producing better results in the future. A progress, no matter how small or trivial it is, can be a starting point on thinking of a higher level task that would challenge an individual to goal for higher heights.

- Needs - Acknowledging self needs can be considered strength because it shows humility and opening a door for assistance. Through the cardex, the teacher can develop remedial activity that can target learners' need.

- Student - - Learners look at cardex as a reminder for them that they don't have other enemy but themselves when progress and achievement is the issue. Also, learners are delighted when they are being monitored, and their progress is the goal of the teacher. 
- Achievement - When achievement is noted, learners are motivated to study well. The learners' achievement is an indication for the teacher for him to develop plans in which this achievement can be utilized for maximum learning and for helping others.

- Life - Cardex is not just seen as a data for monitoring learners' progress, needs and achievement. Students look at this mechanism as guide towards attaining quality life in the future.

- Important - Learners deem the use of cardex as important in and they want to continue doing it on a regular interval to monitor their own progress, needs and achievement. Especially when it is communicated to parents, learners' develop a sense of accountability not only to themselves but also to their parents and the community.

The use of cardex is mandated by the New RPMS-PPST, specifically in the module 12 of the tool. It has two types which was presented on that tool by the Department of Education: one is Template 1 Learner's Needs, Progress and Achievement Cardex, and the other one is Template 2 Parents/Guardian Communication Cardex. Template 1 contains date of reporting, intention of reporting, details of concern, action to be taken, and remarks of action taken. All of these are in-lined with the learner's needs, progress and achievement. This template is the one that the researcher explored and used for the purpose of this study. Template 2 contains date of reporting, type of encounter, details of concern, agreed resolution, signature over printed name, and remarks. This template would be the one to be added as a practice of the researcher for the second semester because it was seen that the use of cardex is beneficial in assisting learners.

\subsection{Homeroom Guidance Program}

Table 4. Word count of homeroom guidance program qualitative response

\begin{tabular}{|c|c|c|}
\hline Index & Word & Occurrences \\
\hline 1 & God & 16 \\
\hline 2 & learn & 14 \\
\hline 3 & symposium & 10 \\
\hline 4 & guidance & 10 \\
\hline 5 & breakfast & 9 \\
\hline 6 & homeroom & 9 \\
\hline 7 & know & 9 \\
\hline 8 & helps & 9 \\
\hline 9 & program & 8 \\
\hline 10 & important & 8 \\
\hline 11 & good & 7 \\
\hline 12 & gives & 7 \\
\hline 13 & things & 7 \\
\hline 14 & teacher & 6 \\
\hline 15 & activity & 6 \\
\hline 16 & students & 6 \\
\hline 17 & student & 6 \\
\hline 18 & knowledge & 6 \\
\hline 19 & life & 5 \\
\hline 20 & help & 4 \\
\hline 21 & like & 4 \\
\hline 22 & bonding & 4 \\
\hline 23 & learning & 4 \\
\hline 24 & bond & 4 \\
\hline 25 & New & 4 \\
\hline
\end{tabular}




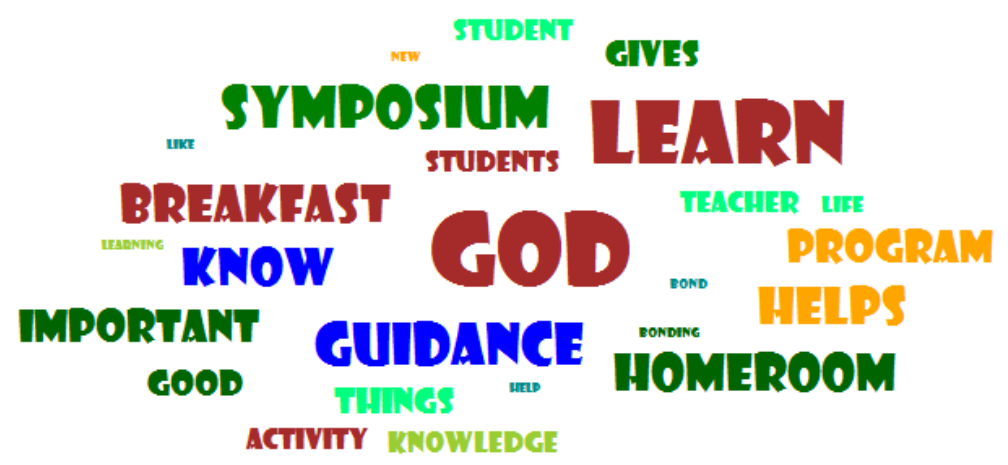

Fig. 5. Word cloud of homeroom guidance program qualitative response

Lastly, to aid in the individual education planning, homeroom guidance program was investigated through the response of the learners in the open-ended written interview done by the researchers. It is seen in their responses that seven words are the usual input: God, learn, symposium, know, helps, teacher and students. From these, seven themes were developed.

- God - The learners appreciate much the conversation about God and the Bible during the homeroom guidance program. The curriculum for SHS focus mainly on academics and skills, and so learners are interested with discussion that is not usual in their one week attendance in school.

- Learn - During homeroom guidance program, students not just do clean the room and the surrounding or prepared things that they were not able to do at home. They also learn stuff that are practical and of moral value.

- Symposium/Activity - Homeroom guidance program should be focused, with target, and planned. That is why activities like symposium, breakfast with devotion, and other similar activity can indeed refresh the mind and soul of the learners.

- Know - Through homeroom guidance program, teachers can have knowledge of the strengths, weakness, interest and background of learners. Sharing of experience is given an opportunity so that the teacher can have a follow up on what is already happening with his advisory class.

- Helps - Learners see the homeroom guidance program as a great help for them because the barrier between learners and teacher is taken out of its way. The teacher shares lifelong lesson through storytelling, journal writing and moments of introspection through God's word.

- Teacher - The teacher is benefitted in such a way that he is able to strategize in his next lesson planning by providing activities that would meet learners' interest and needs. He is also able to win learners' trust because he acts as a guidance counselor during homeroom guidance program.

- Students - Students are benefitted because they are more motivated to go to school, learn, and participate in activities, knowing that they are accepted even with their weaknesses and shortcomings. Teachers and classmates are there for every learner because friendship and support system is being initiated through homeroom guidance program.

Homeroom guidance program has been implemented before the onset of the Enhanced Basic Education Act of 2013. The implementation of the revitalized Homeroom Guidance Program (RHGP), D.O. 67, s. 1997 has the following two objectives: (1) Develop the student's personality through an understanding of self and environment, and (2) Discover/enhance the aptitude/interests of the student to prepare him/her for the world of work and higher academic or non-academic studies. In the K-to-12 curriculum, it was replaced by ESP (Edukasyon sa Pagpapahalaga) but the SHS has none of this program. Because of the result found in this study, it is seen that SHS advisers should find time with their advisory class to institute a homeroom guidance program even once a week through an organized activity like symposium, Bible study, forum, and 
other beneficial activities.

\subsection{Academic Performance}

Table 5. First and second quarter general average of academic learners in Talangan Integrated National High School, s.y. 2019-2020

\begin{tabular}{|c|c|c|c|}
\hline Student & $\begin{array}{c}\text { First Quarter } \\
\text { Average }\end{array}$ & $\begin{array}{l}\text { Second } \\
\text { Quarter } \\
\text { Average }\end{array}$ & Increase \\
\hline 1 & 89 & 92 & 3.00 \\
\hline 2 & 88 & 88 & 0.00 \\
\hline 3 & 84 & 84 & 0.00 \\
\hline 4 & 90 & 92 & 2.00 \\
\hline 5 & 84 & 84 & 0.00 \\
\hline 6 & 83 & 85 & 2.00 \\
\hline 7 & 88 & 88 & 0.00 \\
\hline 8 & 80 & 79 & -1.00 \\
\hline 9 & 85 & 87 & 2.00 \\
\hline 10 & 80 & 85 & 5.00 \\
\hline 11 & 84 & 86 & 2.00 \\
\hline 12 & 85 & 87 & 2.00 \\
\hline 13 & 85 & 87 & 2.00 \\
\hline 14 & 84 & 85 & 1.00 \\
\hline 15 & 92 & 94 & 2.00 \\
\hline 16 & 83 & 84 & 1.00 \\
\hline 17 & 85 & 84 & -1.00 \\
\hline 18 & 85 & 86 & 1.00 \\
\hline 19 & 83 & 84 & 1.00 \\
\hline 20 & 91 & 93 & 2.00 \\
\hline 21 & 89 & 90 & 1.00 \\
\hline 22 & 88 & 89 & 1.00 \\
\hline 23 & 88 & 89 & 1.00 \\
\hline 24 & 89 & 88 & -1.00 \\
\hline 25 & 82 & 82 & 0.00 \\
\hline 26 & 85 & 87 & 2.00 \\
\hline 27 & 90 & 90 & 0.00 \\
\hline 28 & 89 & 91 & 2.00 \\
\hline 29 & 88 & 89 & 1.00 \\
\hline 30 & 83 & 82 & -1.00 \\
\hline 31 & 91 & 91 & 0.00 \\
\hline 32 & 91 & 92 & 1.00 \\
\hline 33 & 92 & 93 & 1.00 \\
\hline 34 & 93 & 94 & 1.00 \\
\hline 35 & 89 & 90 & 1.00 \\
\hline 36 & 90 & 91 & 1.00 \\
\hline 37 & 89 & 91 & 2.00 \\
\hline 38 & 92 & 94 & 2.00 \\
\hline 39 & 90 & 89 & -1.00 \\
\hline 40 & 89 & 90 & 1.00 \\
\hline 41 & 89 & 92 & 3.00 \\
\hline
\end{tabular}

The table above page shows the first and second quarter general average of 41 academic learners of Talangan Integrated National High School. This was composed of 22 General Academic Strand learners and 19 Accountancy, Business and Management learners. The right part of the table shows the increment in general average, or if negative in sign decrease in academic performance. It can be seen that majority of the learners increased in academic performance, with only five learners having a decrease in general average. 
This shows that components of individual education program, that is, home visitation, learners' cardex, and homeroom guidance program helped in the motivation and encouragement of learners to do better in terms of academic performance.

\section{Conclusion, Recommendation and Reflection}

\subsection{Conclusion}

To answer the questions posted at the beginning of the study, the following findings were listed below.

The learners view home visitation as channel of acquiring basic knowledge for the learners' situation at home, way of uplifting learners' by showing concern to his life outside school, teacher's basis for management of lesson and learners in classroom setting, important for learners acquisition of confidence in being his real self at home and inside the classroom, assessment of background of learners so teachers can institute appropriate discipline inside the classroom, collaboration with learners' family in ensuring utmost performance of learners, and school's duty to relate to community as part of learners' environment.

The use cardex is seen by learners as source of basic knowledge of learners' strength and weaknesses, a monitoring agent that guides learners' progress on a task or challenges he is encountering, an assessment of learners' needs and how teachers and parents can help, a reminder to learners that everyone is unique and they need not to compare themselves to others, a reward in itself when learners realize their achievements, a mirror of learners life path which aids them in inner introspection, and an important mechanism that aids learners in regular assessment of their development.

The implementation of homeroom guidance program was perceived by learners as a way of nurturing themselves in other aspect of human development like spirituality, a venue for learning and relearning lessons taught in schools, a beneficial intervention when planned with specific activity, a time set for learners and teachers to know and be acquainted with each other, a special way to take away barrier between teacher and learner or between learners themselves, an avenue that will aid teachers in developing lessons suited for the learners needs, and a way to provide guidance for learners and motivate them to schooling.

Through the aid of individual education program which consists of home visitation, learner's cardex, and homeroom guidance program, learners are encouraged, guided and motivated, thus having improvement in academic performance.

\subsection{Recommendations}

Based from the findings and conclusion made as a result of this study, the following recommendations are entrusted to the following group of people:

- Teachers - Home visitation maybe an additional task, but nonetheless a fruitful endeavor when becomes a routine or SOP of teachers during the onset of new school year when advisory learners are just beginning to explore the new grade or stage of learning. Proper guidance of teachers or advisers, being the second parents of the youth in school, helps in boosting learners' performance. Teachers are encouraged to not only home visitation but also having a strong homeroom guidance program where they can learn the strengths and weaknesses of the learners. Instituting a quarterly learner's cardex to assess their needs, progress and achievement will guide teachers in knowing how to best guide them throughout the whole school year.

- Parents - Collaboration with school effort in educating young minds is a task for parents amidst challenges of raising money for food, shelter and clothing. As the Filipino maxim goes, "Education is the best heritage that parents can give to their child," being partners with teachers and school is part of their dream of giving their children the best heritage that they can relinquish to them. 
Teachers or school alone cannot give quality education when parents are complacent or indifferent with schools effort of bringing out the best in their children.

- School heads - An important catalyst in realizing the role of individual education planning are the school heads. Unless they lead the teachers in developing a system of individually knowing all learners and having a profile of them ready for use in educational planning, the best out of every learner would not be achieved. Therefore, school heads should first be the proponent of individual education planning (IEP), and all teachers will follow if properly guided and the concepts of IEP are well explained to them.

- Curriculum developers - The competencies, budget of work, materials and all aspects connected to curriculum should be flexible in such a way that it allows space for teachers to insert make adjustments of innovation so as to fit the learner' needs, interest, gender, experience and ability. Curriculum developers are thus challenged to focus on producing differentiated instructions as guide for teachers, especially the new ones.

- Future researchers - Triangulation would best enhance or innovate this present research. Teachers, parents and the community can be added to learners as respondents for future study so as to explore more on Individual Education Planning (IEP). How the parents and teachers look at home visitation, use of learners' cardex, and implementation of strong homeroom guidance program would greatly help teachers, school heads and curriculum developers in making a strong Individual Education Program that would best cater to $21^{\text {st }}$ century learners. Thus, the continuation of this study on a larger scale is recommended.

\subsection{Reflection}

Though much has been known on the aspect of education through centuries of study and innovation, much is still to be explored, especially because the nature of learners continues to evolve across decades. As different principles come out so as to address learners' needs, the program itself that corresponds to those principle is needed for implementation and not just planning.

Throughout the conduct of this study, the researcher was able to see how vast is the field of education that he himself is being is continued to be challenged with the ever changing need of learners so as to reach them and cultivate in them the value of discovering their uniqueness. Guiding them in discovering this is a crucial role of teachers, so much more the adviser. Therefore, the findings and conclusion that he found out in this study gave him commitment in continuing to pursue the calling of teaching, and the passion for learning because it is a lifelong journey.

\section{References}

Adjei, A. et. al. (June 2008). Parent-community involvement in school governance and its effects on teacher effectiveness and improvement of learner performance: A study of selected primary and secondary schools in Botswana Department of Geography University of the Free State (Qwaqwa Campus) South Africa.

Bennett, Barrie, Rolheiser-Bennett, Carol \& Stevahn, Laurie (1991). Cooperative Learning: Where Heart Meets Mind. Toronto: Educational Connections.

Bennett, Barrie \& Rolheiser, Carol (2001). Beyond Monet: The Artful Science of Instructional Integration. Toronto: Bookation Inc. Borba, M. (2009). Caring closes the language-learning gap: Investing in developing caring relationships between school and the families of English learners pays off in parental support for education and improved learning for students. The Education Digest, 75(2), 21-25. GS SEARCH.

Byrd, D. R. (May 2012). Conducting Successful Home Visits in Multicultural Communities. Weber State University. Journal of Curriculum and Instruction (JoCI). Vol. 6, No. 1, Pp. 43-54 ISSN: 1937-3929.

Creswell, J.W. (2003). Research Design: Qualitative, Quantitative, and Mixed Approaches (2 ${ }^{\text {nd }}$ ed.). Thousand Oaks, CA: Sage. 2003

Epstein, J. (1995). School/family/community partnerships: Caring for the children we share. Phi Delta Kappan. 76(3), 701-712. GS SEARCH. 
Gichohi, G. W. (February 2015). International Journal of Education and Research Vol. 3 No. 2 Stakeholder involvement in Schools in 21st Century for Academic Excellence

Gorter-Reu, M., \& Anderson, J. (1998). Home kits, home visits and more! Young Children, 53(3), 71-74. GS SEARCH.

Individualized Educational Planning. (2005). Special Education Coordinator, Department of Education. PO Box 2000, Charlottetown, PE C1A $7 \mathrm{~N} 8$

NEA Education Policy and Practice Department. (2013). Planning for School Restructuring: Keeping Stakeholders in the Process Engaging Stakeholders Including Parents and the Community to Sustain Improved Reading Outcomes. SUSTAINING READING FIRST Sustainability Series.

Pascual, E.A. (2019). “Essentials of Home Visitation: Teachers', Learners' and Stakeholders' View”, Lambert Academic Publishing, Mauritius.

Porter, Gordon L. (1994). Executive Producer. Teachers Helping Teachers: Problem Solving Teams that Work. Video \& Manual. Toronto: The Roeher Institute and School District No. 12, New Brunswick.

Roekel, D. V. (2008). NEA Education Policy and Practice Department. Parent, Family, Community Involvement in Education. 1201 16th St., NW, Washington, D.C. 20036 policy brief.

Schmit, S. et.al. (2015). Effective, Evidence-Based Home Visiting Programs in Every State at Risk if Congress Does Not Extend Funding. 820 First Street, NE, Suite 510, Washington, DC.

Tasmanian Department of Education. Conducting Home Visits Procedures Department of Education. (n.d.). Learners first, connected and inspired. Tasmanian Department of Education website.

Te Puri Kokiri. (2007). Communicating with stakeholders. Retrieved from https://www.tpk.govt.nz/documents/.../93/tpkcommicatewithstakeholders-2007.pdf

Tomlinson, Carol Ann. (2001). How to differentiate instruction in a mixed ability classroom, 2nd Edition. Alexandria, VA: ASCD

Tondi, G. D. (2014). Analysis of Stakeholders' Views on the Quality of Education in Community Secondary Schools in Moshi Rural District. A Dissertation submitted in Partial Fulfillment of the Requirements for the Degree of Master of Educaiton in Administration, Planning and Policy in the Open Univeristy of Tanzania.

UNESCO (2004). Changing Teaching Practices: Using Curriculum Differentiation to Respond to Students' Diversity. France: UNESCO. Wang, M.C. and Haertel, G.D. (n.d.). A digest of research from tehLaboratory for Student Success Teacher Relationships. 